\title{
Treatment of Severe Atopic Dermatitis with Cyclosporine: A Review of Eight Patients
}

\author{
Lidija KANDOLF SEKULOVIĆ ${ }^{1}$, Kristina KOSTIĆ Željko MIJUŠKOVIĆ $^{1}$, Miroslav DINIĆ², \\ Lidija CVETKOVIĆ JORDANOV², Radoš ZEČEVIĆ ${ }^{1}$
}

${ }^{1}$ Department of Dermatovenereology, Faculty of Medicine, Military Medical Academy, University of Defence, Belgrade

${ }^{2}$ Department of Dermatovenereology, Military Medical Academy, Belgrade

${ }^{*}$ Correspondence: Lidija Kandolf Sekulović, E-mail: lkandolfsekulovic@gmail.com

UDC 616.5-002:615.37

VERSITA

\begin{abstract}
Atopic dermatitis is most frequently well controlled with topical therapeutic agents, but based on several studies, $10-20 \%$ of patients need systemic therapy. The most common systemic treatment for atopic dermatitis in everyday practice includes systemic corticosteroids, although there are insufficient valid data to support this. Cyclosporine is the treatment of choice for severe atopic dermatitis resistant to other commonly used treatment options, since its favorable therapeutic risk/benefit ratio is well documented in randomized placebo controlled trials, and also in uncontrolled trials. However, approximately $10 \%$ of patients with atopic dermatitis with indication for cyclosporine treatment are actually treated with this modality in Serbia, and there are no published case series on its use in this region so far. In this article, we evaluated the treatment efficacy and safety of cyclosporine microemulsion in patients with severe atopic dermatitis hospitalized at the Military Medical Academy in Belgrade from 2009 to 2012. This restrospective analysis included patients with severe forms of atopic dermatitis treated at the Department of Dermatology of the Military Medical Academy from 2009 - 2012. The hospital database was used to retrieve patients' medical records. Approximately 200 patients were treated for atopic dermatitis and 20 patients were admitted to the hospital, 17 due to severe forms of disease. In total, 8 of 17 (47.05\%) hospitalized patients with severe forms or erythroderma due to atopic dermatitis were treated with cyclosporine microemulsion with an initial dose of $4-5 \mathrm{mg} / \mathrm{kg}$. Laboratory tests were done before treatment, 7 days later, and/or at the end of hospitalization. Therapeutic efficacy was evaluated based on the percentage of reduction of skin lesions from baseline to the end of hospital treatment (early efficacy), and at the end of follow-up (late efficacy). Duration of therapy, adverse events, treatment efficacy and reasons for treatment cessation were recorded during the follow-up period. There were five male and 3 female patients, with an average age of 36.8 years (15-60 years). Previous treatment modalities in all patients included emollients, topical and systemic corticosteroids and PUVA therapy. The average dose of cyclosporine was $4.5 \pm 0,5 \mathrm{mg} / \mathrm{kg}$. Median reduction of skin lesions at discharge was $60 \%$. There was no need for further hospitalization after an average of $10 \pm 3.2$ days. Mean duration of treatment was 16 months (3 - 24), with an average reduction of skin lesions of $75 \%$ during follow-up. Arterial blood pressure increased in $3 / 8(37.5 \%)$ patients, regardless of their age, with and average increase of systolic blood pressure of $11.9 \pm 11.6 \mathrm{~mm}$ $\mathrm{Hg}$ (median 7.5, 0-30 mm Hg) and diastolic blood pressure of 5.6 $\pm 12.9 \mathrm{~mm} \mathrm{Hg}$ (median 0, -10-20). Mean increase in urea concentration was $0.3 \mathrm{mmol} / \mathrm{L}(11.8 \%$ ) and creatinine increased only in three patients by $4.2 \%$ (median increase $4 \mathrm{mmol} / \mathrm{L}$ ). Hypertension was found in three patients during follow-up, and there were no other adverse events. In conclusion, based on previous studies and this small case series of hospitalized patients with severe forms of atopic dermatitis including erythroderma, cyclosporine can be regarded as a safe and effective treatment modality and it can be recommended as first line therapy in severe forms of atopic dermatitis refractory to topical therapy and phototherapy. Long term therapy, however, should be avoided and a maximum 1-2 year therapy is recommended.
\end{abstract}

\section{Key words}

Dermatitis, Atopic; Cyclosporine; Treatment Outcome; Immunosuppressive Agents 
A topic dermatitis (AD) is a chronic inflammatory immune-mediated skin disease, that affects $20 \%$ of children and up to $10 \%$ od adults in developed countries. Most frequently it is well controlled with topical therapeutic modalities. Emollients, topical corticosteroids of mild to moderate potency, and topical calcineurin inhibitors are quite efficient in controlling symptoms and signs in the majority of cases (1). However, based on several studies, 10$20 \%$ of patients need systemic therapy (2). Systemic immunosuppressive treatment is an option reserved for severe cases. The most common systemic treatment for atopic dermatitis in everyday practice includes systemic corticosteroids, although there are insufficient valid data to support this $(1,2)$. Their unfavorable risk/benefit ratio is evident in long term use in $\mathrm{AD}$ patients. The most commonly used adjuvant modalities include ultra violet (UV) phototherapy, evaluated in detail in the treatment of $\mathrm{AD}$. This is especially true for narow band (nb) UVB phototherapy, which is considered to be the first line phototherapy option for relieving pruritus in chronic pruritic lichenified forms of the disease (1-3).

Cyclosporine is the treatment of choice for severe atopic dermatitis resistant to other commonly used treatment options. Its favorable therapeutic risk/benefit ratio is well documented in randomized placebo controlled trials, and also in uncontrolled trials (4-6). According to recent therapeutic guidelines for atopic dermatitis published in 2012 by the European Academy of Dermatology and Venereology, cyclosporine should be used in severe chronic forms of atopic dermatitis in a maximum daily dose of $5 \mathrm{mg} / \mathrm{kg}$ in two single doses (3). A slow dosage tapering of 0.5$1 \mathrm{mg} / \mathrm{kg} /$ day every 2 weeks, depending on treatment effects, is advised after achieving desirable therapeutic efficacy. Long term treatment, however, is not advised and treatment should be ceased after 2 years (3).

In Serbia, cyclosporine is indicated in: solid organ transplant recepients, patients with bone marrow transplantation, nephrotic syndrome, rheumatoid arthritis, endogenous uveitis, psoriasis and atopic dermatitis, and is reimbursed for organ transplant recepients and severe autoimmune diseases. However, approximately only $10 \%$ of $\mathrm{AD}$ patients are actually treated with this modality and there are no published case series on its use in this region so far. In this article, we evaluated the treatment efficacy and safety of cyclosporine microemulsion in patients with severe atopic dermatitis hospitalized at the Military Medical Academy (MMA) in Belgrade from 2009 to 2012.

\section{Patients and methods}

This retrospective analysis included patients with severe forms of atopic dermatitis treated at the Department of Dermatology of the Military Medical Academy in Belgrade from January 1, 2009 to January 1, 2012. The hospital database was used to retrieve patinets' medical records. Atopic dermatitis was diagnosed based on clinical criteria proposed by Hanifin and Rajka (7).

In the period from 2009 to 2012, two hundred patients were treated for atopic dermatitis at the Military Medical Academy in Belgrade. During this period, 20 patients were admitted to the hospital, 17 due to a severe form of the disease. Erythroderma due to atopic dermatitis was defined as involvement of more then $90 \%$ of skin surface, while the severe form of AD was defined as involvement of more then $70 \%$ of skin surface (suberythroderma), or involvement of more than $50 \%$ of skin surface with resistance to other treatment options. In total, 8 of $17(47.05 \%)$ hospitalized patients with severe forms of $\mathrm{AD}$ were treated with cyclosporine microemulsion with an initial dose of 4-5 $\mathrm{mg} / \mathrm{kg}$. Laboratory tests were done before treatment, 7 days later and/or at the end of hospitalization. Early therapeutic efficacy was evaluated on the last day of hospitalization based on the percentage of skin lesion reduction related to the percentage before treatment. Intensive local treatment with emollients and topical corticosteroids was used as concomitant therapy, as well as oral antihistamines in $7 / 8$ (87.5\%) patients. Duration of therapy, adverse events, treatment efficacy and reasons for treatment cessation were recorded during the follow-up of patients.

\section{Results}

Baseline disease characteristics of $\mathrm{AD}$ patients treated with cyclosporine microemulsion are presented in Table 1.

There were 5 male and 3 female patients, with an average age of 36.8 years ( $15-60$ years). In five patients the disease started in childhood, while in three it was adult-onset atopic dermatitis. On admission, three 
Table 1. Baseline disease characteristics of atopic dermatitis patients (before treatment)

\begin{tabular}{|c|c|c|c|c|c|c|c|c|c|}
\hline Patient & Sex & Age & $\begin{array}{c}\text { Age } \\
\text { of } \\
\text { onset }\end{array}$ & $\begin{array}{c}\text { Clinical } \\
\text { manifestation }\end{array}$ & $\begin{array}{l}\text { Manifested } \\
\text { allergic } \\
\text { rhinitis or } \\
\text { asthma }\end{array}$ & $\begin{array}{l}\text { Prick } \\
\text { tests }^{*}\end{array}$ & $\begin{array}{c}\text { IgE }^{* *} \\
(\mathrm{IU} / \mathrm{ml})\end{array}$ & Eosinophilia*** & $\begin{array}{c}\text { Previous } \\
\text { treatment } \\
\text { modalities }\end{array}$ \\
\hline 1. & $\mathrm{~F}$ & 60 & 55 & erythroderma & no & no & 539 & no & $\mathrm{tCS}, \mathrm{sCS}$ \\
\hline 2. & M & 30 & 24 & erythroderma & no & no & 24700 & no & $\begin{array}{c}\mathrm{tCS}, \mathrm{sCS} \\
\text { PUVA }\end{array}$ \\
\hline 3. & M & 27 & 14 & erythroderma & yes & yes & 6750 & no & $\mathrm{tCS}, \mathrm{sCS}$ \\
\hline 4. & M & 52 & 32 & severe $\mathrm{AD}$ & yes & yes & 19300 & yes & $\mathrm{tCS}, \mathrm{sCS}$ \\
\hline 5. & $\mathrm{~F}$ & 30 & 20 & severe $\mathrm{AD}$ & no & yes & 530 & no & $\mathrm{tCS}, \mathrm{sCS}$ \\
\hline 6. & $\mathrm{~F}$ & 15 & 7 & severe $\mathrm{AD}$ & no & yes & 171 & yes & $\mathrm{tCS}$ \\
\hline 7. & M & 25 & 7 & severe $\mathrm{AD}$ & yes & yes & 969 & no & $\mathrm{tCS}$ \\
\hline 8. & M & 56 & 53 & severe $\mathrm{AD}$ & no & no & 80 & no & $\mathrm{tCS}$ \\
\hline
\end{tabular}

${ }^{*}$, positive prick tests to common inhalatory allergens; ${ }^{* *}$ serum IgE level; ${ }^{* * *}$ blood eosinophilia; tCS - topical corticosteroids; sCS - systemic corticosteroids; PUVA - psoralen ultraviolet A irradiation

patients also had manifestations of allergic rhinitis and bronchial asthma. The mean $\operatorname{IgE}$ concentration was $754 \mathrm{IU} / \mathrm{ml}$ (80-24700), 7/8 (87.5\%) patients had serum immunoglobulin E (IgE) levels above 100 $\mathrm{IU} / \mathrm{ml}$, and in 3 patients $\mathrm{IgE}$ was above $1000 \mathrm{IU} /$ $\mathrm{ml}$. Eosinophilia was noted in $2 / 8(25 \%)$ patients. Previous treatment modalities in all patients included emollients, topical and systemic corticosteroids, while one patient was also treated with psoralen plus ultra violet A (PUVA) therapy (Table 1).

The initial dose of cyclosporine was $4 \mathrm{mg} / \mathrm{kg} /$ day in four patients and $5 \mathrm{mg} / \mathrm{kg} /$ day in another four patients, with the average dose of $4.5 \pm 0,5 \mathrm{mg} / \mathrm{kg} /$ day. The first therapeutic effects were evaluated at discharge showing $60 \%$ mean reduction of skin lesions. There was no need for further hospitalization after an verage of $10 \pm 3.2$ days. Finally, taking into account further follow-up, mean duration of treatment was 16 months (3 - 24), with an average reduction of $75 \%$ of skin lesions. In 3 patients the treatment was discontinued when satisfying clinical response was achieved, and in 5 when the maximum recommended length of treatment was over with a reduction of $75 \%$ of skin lesions. Cyclosporine was tapered to a minimum average dose of $1.45 \mathrm{mg} / \mathrm{kg} /$ day at the end of treatment. The treatment parameters are presented in Table 2.

Blood pressure and serum levels of urea and creatinine, measured at baseline and at discharge, as well as adverse events during the follow-up period are presented in Table 3. Arterial blood pressure increased in $3 / 8(37.5 \%)$ patients, regardless of age, with and average increase of systolic blood pressure of $11.9 \pm 11.6 \mathrm{~mm} \mathrm{Hg}$ (median 7.5, range $0-30$

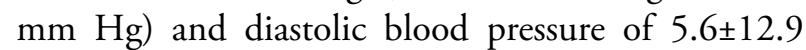
$\mathrm{mm} \mathrm{Hg}$ (median 0, range $-10-20$ ). Mean increase in urea concentration was $0.3 \mathrm{mmol} / \mathrm{L}(11.8 \%)$ and creatinine increased only in three patients by $4.2 \%$ (mean increase $4 \mathrm{mmol} / \mathrm{L}$ ). Hypertension was recorded in three patients during follow-up, and there were no other adverse events.

\section{Discussion}

Atopic dermatisis, or atopic eczema is a chronic, relapsing inflammatory skin disease commonly 
Table 2. Treatment parameters of $\mathrm{AD}$ patients treated with cyclosporine

\begin{tabular}{|c|c|c|c|c|c|c|c|}
\hline Patient & $\begin{array}{c}\text { Initial } \\
\text { dose } \\
(\mathrm{mg} / \mathrm{kg})\end{array}$ & $\begin{array}{c}\text { Duration of } \\
\text { hospitalization } \\
\text { (days) }\end{array}$ & $\begin{array}{l}\text { Treatment } \\
\text { efficacy at } \\
\text { discharge } \\
\text { (\% of skin } \\
\text { lesion } \\
\text { regression) }\end{array}$ & $\begin{array}{l}\text { Duration } \\
\quad \text { of } \\
\text { treatment } \\
\text { (months) }\end{array}$ & $\begin{array}{c}\text { Treatment } \\
\text { efficacy at the } \\
\text { end of follow-up } \\
\text { (\% of skin lesion } \\
\text { regression) }\end{array}$ & $\begin{array}{c}\text { Dose of } \\
\text { cyclosporine } \\
\text { before } \\
\text { withdrawal } \\
(\mathrm{mg} / \mathrm{kg})\end{array}$ & $\begin{array}{l}\text { Reasons for } \\
\text { withdrawal } \\
\text { of treament }\end{array}$ \\
\hline 1. & 5 & 12 & 70 & 14 & 75 & 0.4 & $\begin{array}{c}\text { satisfying } \\
\text { efficacy }\end{array}$ \\
\hline 2. & 4 & 7 & 50 & 12 & 75 & 1.5 & $\begin{array}{c}\text { duration of } \\
\text { treatment }\end{array}$ \\
\hline 3. & 4 & 14 & 50 & 3 & 75 & 1.5 & $\begin{array}{l}\text { satisfying } \\
\text { efficacy }\end{array}$ \\
\hline 4. & 5 & 15 & 90 & 6 & 100 & 2 & $\begin{array}{l}\text { complete } \\
\text { regression }\end{array}$ \\
\hline 5. & 5 & 9 & 70 & 18 & 75 & 1.4 & $\begin{array}{c}\text { duration of } \\
\text { treatment }\end{array}$ \\
\hline 6. & 4 & 8 & 70 & 24 & 100 & NA & $\begin{array}{c}\text { duration of } \\
\text { treatment }\end{array}$ \\
\hline 7. & 4 & 8 & 50 & 24 & 100 & 1.25 & $\begin{array}{c}\text { duration of } \\
\text { treatment }\end{array}$ \\
\hline 8. & 5 & 7 & 50 & 24 & 75 & NA & $\begin{array}{c}\text { duration of } \\
\text { treatment }\end{array}$ \\
\hline Mean \pm SD & $4.5 \pm 0.5$ & $10 \pm 3.2$ & $62.5 \pm 14.8$ & $15.6 \pm 8.3$ & $84.3 \pm 12.9$ & $1.34 \pm 0.5$ & - \\
\hline $\begin{array}{l}\text { Mean } \\
\text { min-max }\end{array}$ & $\begin{array}{l}4.5 \\
4-5\end{array}$ & $\begin{array}{c}8.5 \\
7-15\end{array}$ & $\begin{array}{c}60 \\
50-90\end{array}$ & $\begin{array}{c}16 \\
3-24\end{array}$ & $\begin{array}{c}75 \\
75-100\end{array}$ & $\begin{array}{l}1.45 \\
0.4-2\end{array}$ & - \\
\hline
\end{tabular}

affecting persons with personal and family history of atopy, as well as bronchial asthma, and allergic rhinoconjunctivitis. It is one of the most common dermatoses, affecting up to $20 \%$ of children and $5-10 \%$ of adult persons in developed countries (1-4).

In up to $80 \%$ of patients the disease is mild, and it can be contolled with topical treatment. Based on European Guidelines, basic treatment for all stages of $\mathrm{AD}$ is emollient therapy and proper skin care with steroid sparing effects. Addition of topical corticosteroids of mild to moderate potency can efficiently control flareups. In patients with frequent relapses, topical calcineurin inhibitors can provide long-term control of the disease with steroid-sparing effects and prevention of flares (2).

However, up to $10-20 \%$ of patients with moderate or severe AD fail to control flare-ups with topical treatment. They need to use either adjuvant photoherapy or systemic immunosuppressants such as systemic corticosteroids which are most commonly used, and cyclosporine which is considered to be the first line option based on current guidelines (3). Azathioprine, methotrexate and mycophenolate mofetil are used in patients refractory to cyclosporine treatment. In recent years, biologic therapy with infliximab, anti tumor necrosisis factor-alpha (TNF- $\alpha$ ), rituximab (anti CD-20) and omalizumab (anti-IgE antibody) were evaluated in small case series with variable results, and may be considered in the treatment of patients refractory to any other treatment modality including cyclosporine and other forms of immunosuppressive agents (3).

Cyclosporine was evaluated in the treatment of atopic dermatitis in more than 20 clinical trials (24 based on PubMed search), including 10 randomized 
Table 3. Blood pressure and serum levels of urea and creatinine during cyclosporine therapy

\begin{tabular}{|c|c|c|c|c|c|c|c|c|c|c|c|c|c|}
\hline \multirow{2}{*}{ Patient } & \multicolumn{3}{|c|}{$\begin{array}{l}\text { Systolic blood pressure } \\
\qquad(\mathrm{mmHg})\end{array}$} & \multicolumn{3}{|c|}{$\begin{array}{l}\text { Diastolic blood pressure } \\
(\mathrm{mmHg})\end{array}$} & \multicolumn{3}{|c|}{ Urea serum level } & \multicolumn{3}{|c|}{ Creatinine serum level } & \multirow{2}{*}{$\begin{array}{l}\text { Adverse events } \\
\text { during } \\
\text { follow-up }\end{array}$} \\
\hline & Before* & After** & Increase & Before* & After ${ }^{* *}$ & Increase & Before* & After** & Increase & Before* & After** & Increase & \\
\hline 1. & 120 & 125 & 5 & 80 & 85 & 5 & 3.3 & 4.1 & 0.8 & 85 & 75 & - & hypertension \\
\hline 2. & 120 & 150 & 30 & 80 & 100 & 20 & 2.8 & 3 & 0.2 & 74 & 70 & - & hypertension \\
\hline 3. & 120 & 130 & 10 & 80 & 80 & 0 & 5.9 & 5.9 & 0 & 93 & 103 & 10 & none \\
\hline 4. & 110 & 140 & 30 & 80 & 90 & 10 & 6.7 & 7.1 & 0.4 & 105 & 109 & 4 & hypertension \\
\hline 5. & 120 & 125 & 15 & 80 & 80 & 0 & 3.3 & 4.8 & 1.5 & 82 & 76 & - & none \\
\hline 6. & 120 & 120 & 0 & 80 & 70 & -10 & 7.2 & 5.4 & -1.8 & 73 & 49 & - & none \\
\hline 7. & 120 & 125 & 5 & 70 & 70 & 0 & 4 & 4 & 0 & 97 & 101 & 4 & none \\
\hline 8. & 130 & 140 & 10 & 80 & 80 & 0 & 4.4 & 5.9 & 1.5 & 73 & 59 & - & none \\
\hline $\begin{array}{l}\text { Mean } \\
\pm \mathrm{SD}\end{array}$ & $\begin{array}{r}120 \\
\pm 5.3\end{array}$ & $\begin{array}{l}131.8 \\
\pm 10.3\end{array}$ & $\begin{array}{l}13.1 \\
\pm 1.3\end{array}$ & $\begin{array}{c}76 \\
\pm 7.4\end{array}$ & $\begin{array}{l}81.9 \\
\pm 10\end{array}$ & $\begin{array}{l}3.12 \\
\pm 8.8\end{array}$ & $\begin{array}{c}4.7 \\
\pm 1.7\end{array}$ & $\begin{array}{c}5.0 \\
\pm 1.3\end{array}$ & $\begin{array}{c}0.32 \\
\pm 1.05\end{array}$ & $\begin{array}{c}85.3 \\
\pm 12.1\end{array}$ & $\begin{array}{c}80.3 \\
\pm 21.9\end{array}$ & $\begin{array}{c}6 \\
\pm 3.46\end{array}$ & - \\
\hline $\begin{array}{c}\text { Mean } \\
\text { min-max }\end{array}$ & $\begin{array}{c}120 \\
110-130\end{array}$ & $\begin{array}{c}127.5 \\
120-150\end{array}$ & $\begin{array}{c}10 \\
0-30\end{array}$ & $\begin{array}{c}80 \\
60-80\end{array}$ & $\begin{array}{c}80 \\
70-100\end{array}$ & $\begin{array}{c}0 \\
-10-20\end{array}$ & $\begin{array}{c}4.2 \\
2.8-7.2\end{array}$ & $\begin{array}{c}5.1 \\
3-5.9\end{array}$ & $\begin{array}{c}0.3 \\
-1.8-1.5\end{array}$ & $\begin{array}{l}83.5 \\
73-105\end{array}$ & $\begin{array}{c}75.5 \\
70-109\end{array}$ & $\begin{array}{c}4 \\
4-10\end{array}$ & - \\
\hline
\end{tabular}

* - before treatment; ${ }^{* *}$ - after hospitalization

controlled trials. A placebo controlled trial design was used in 3 studies; 3 studies were on cyclosporine efficacy in relation to two different doses, different formulations and intermittent vs. continuous treatment, respectively, and the remaining 4 studies compared cyclosporine to topical tacrolimus, systemic corticosteroids and enteric coated mycophenolate mofetil, respectively $(5,6,8-15)$. Based on these studies and given the fact that there are no available trials evaluating systemic corticosteroids with unfavorable benefit/risk ratio, cyclosporine is nowadays regarded to be the first line therapy for severe forms of atopic dermatitis refractory to topical therapy and phototherapy. Microemulsions of cyclosporine show an earlier onset of peak values of efficacy compared to enteric coated mycophenolate mofetil, while in the maintenance phase both drugs are equally effective. In the study comparing cyclosporine therapy with systemic corticosteroids, a 6-week therapy with cyclosporine was more effective than 2-week therapy with systemic corticosteroids, but the duration of treatment was significantly shorter in the group of patients treated with corticosteroids with fast dose tapering (15). Interestingly, in one randomized study that compared effects of topical treatment with tacrolimus ointment $0.1 \%$ and oral cyclosporine in adult patients affected by atopic dermatitis, tacrolimus ointment was more effective than oral cyclosporine 3 $\mathrm{mg} / \mathrm{kg} /$ day after 14-35 days of treatment (12).

The initial dose of cyclosporine in our study was $4.5 \mathrm{mg} / \mathrm{kg} /$ day on average, close to the maximum recommended dose for $\mathrm{AD}$, since this group of patients was considered to have severe $\mathrm{AD}$ refractory to other treatments. The usual recommended initial dose in moderate-to-severe atopic dermatitis is 2.5-3.5 $\mathrm{mg} / \mathrm{kg} /$ day and should be increased to a maximum of 
$5 \mathrm{mg} / \mathrm{kg} /$ day. Microemulsions of cyclosporine show an earlier onset (usually after 14 days) of peak efficacy compared to traditional formulations. In our patients, a significant partial regression of atopic dermatitis (when there was no further need for hospitalization), was achieved after 10 days on average. Higher initial dose and more intensive local therapy with emollients and topical corticosteroids contributed to the observed efficacy. After hospitalization, cyclosporine was tapered by $0.5-1 \mathrm{mg} / \mathrm{kg} /$ day every $2-4$ weeks after clinical efficacy was achieved.

In our study, the safety of cyclosporine was confirmed by clinically insignificant increase of urea and creatinine serum levels, which were not above the reference values. The average increase in systolic blood pressure was $10 \mathrm{~mm} \mathrm{Hg}$ and of diastolic blood pressure $5 \mathrm{~mm} \mathrm{Hg}$, which did not compromise the treatment. During the follow-up period, hypertension was found in three patinets, but did not compromise the treatment. The duration of treatment was 3-24 months. Long term therapy, however, should be avoided and a maximum 1-2 year therapy is recommended in order to avoid potential side effects. Since continuous oral administration of the calcineurin inhibitor - cyclosporine is associated with an increased photocarcinogenicity risk in solid organ transplant patients, UV protection with sunscreens is advised. In regard to the lymphoma risk, diagnosis of $\mathrm{AD}$ is associated with an increased risk for lymphoma. Moreover, risk-adjusted analysis showed that severity of $\mathrm{AD}$ was associated with a 3-fold increase in the risk of lymphoma (16). It is possible that misclassification of cases is partially responsible for the increased risk of lymphoma found in patients with severe AD. High incidence of mycosis fungoides (MF) among cases makes misdiagnosis a plausible hypothesis. MF and Sezary syndrome may present with cutaneous manifestations that resemble chronic severe adult $\mathrm{AD}$ and it is possible that some cases were in fact MF cases that had been misdiagnosed as $\operatorname{AD}(17,18)$. In our study, atopic dermatitis was diagnosed based on clinical criteria by Hanifin and Rajka (7). The main limitation of our study was its retrospective character. Since Hanifin and Rajka published their diagnostic criteria, clinical features are critically evaluated, and it is suggested that in addition to the presence of at least 2 of 3 principal criteria (pruritus, typical morphology and distribution, chronic or chronically relapsing course), the presence of allergen-specific IgE, should be mandatory for diagnosis. In patients who fulfill the principal criteria, but in whom allergen-specific IgE cannot be detected, even on repeated occasions, a number of diagnoses in which atopic dermatitislike symptoms may occur should be excluded: Wiskott-Aldrich syndrome, hyper-IgE syndrome, phenylketonuria, Netherton's syndrome, Job's syndrome, agammaglobulinemia, IgA defficiency, ataxia telangiectasia and so on (19).

In conclusion, based on this small case series of hospitalized patients with severe forms of atopic dermatitis including erythroderma, cyclosporine may be regarded as a safe and effective treatment modality and it can be recommended as the first line therapy in severe forms of atopic dermatitis refractory to topical therapy and phototherapy.

\section{References:}

1. Kang K, Polster AM, Nedorost ST, Stevens SR, Cooper KD. Atopic dermatitis. In: Bolognia JL, Jorizzo JJ. Dermatology. London: Elsevier; 2008.

2. Ring J, Alomar A, Bieber T, Deleuran M, Fink-Wagner A, Gelmetti C, et al. Guidelines for treatment of atopic eczema (atopic dermatitis): part I. J Eur Acad Dermatol Venereol 2012;26(8):1045-60.

3. Ring J, Alomar A, Bieber T, Deleuran M, Fink-Wagner A, Gelmetti C, et al. Guidelines for treatment of atopic eczema (atopic dermatitis): part II. J Eur Acad Dermatol Venereol $2012 ; 26(9): 1176-93$.

4. Darsow U, Wollenberg A, Simon D, Taïeb A, Werfel T, Oranje A, et al. ETFAD/EADV eczema task force 2009 position paper on diagnosis and treatment of atopic dermatitis. J Eur Acad Dermatol Venereol 2010;24(3):317-28.

5. Salek MS, Finlay AY, Luscombe DK, Allen BR, Berth-Jones J, Camp RD, et al. Cyclosporin greatly improves the quality of life of adults with severe atopic dermatitis: a randomized, double-blind, placebo-controlled trial. $\mathrm{Br} \mathrm{J}$ Dermatol 1993;129(4):422-30.

6. van Joost T, Heule F, Korstanje M, van den Broek MJ, Stenveld HJ, van Vloten WA. Cyclosporin in atopic dermatitis: a multicentre placebo-controlled study. $\mathrm{Br} \mathrm{J}$ Dermatol 1994;130(5):634-40.

7. Hanifin JM, Rajka G. Diagnostic features of atopic dermatitis. Acta Derm Venereol 1980;92:44-7.

8. Czech W, Bräutigam M, Weidinger G, SchöpfE. A body-weightindependent dosing regimen of cyclosporine microemulsion is effective in severe atopic dermatitis and improves the quality of life. J Am Acad Dermatol 2000;42(4):653-9.

9. Harper JI, Ahmed I, Barclay G, Lacour M, Hoeger P, Cork $\mathrm{MJ}$, et al. Cyclosporin for severe childhood atopic dermatitis: short course versus continuous therapy. $\mathrm{Br} \mathrm{J}$ Dermatol 2000;142(1):52-8. 
10. Zurbriggen $B$, Wüthrich $B$, Cachelin $A B$, Wili $P B$, Kägi MK. Comparison of two formulations of cyclosporin $A$ in the treatment of severe atopic dermatitis: a double-blind, singlecentre, cross-over pilot study. Dermatology 1999;198(1):5660.

11. Zonneveld IM, De Rie MA, Beljaards RC, Van Der Rhee HJ, Wuite J, Zeegelaar J, et al. The long-term safety and efficacy of cyclosporin in severe refractory atopic dermatitis: a comparison of two dosage regimens. Br J Dermatol 1996;135(Suppl 48):15-20.

12. Pacor ML, Di Lorenzo G, Martinelli N, Mansueto P, Rini GB, Corrocher R. Comparing tacrolimus ointment and oral cyclosporine in adult patients affected by atopic dermatitis: a randomized study. Clin Exp Allergy 2004;34(4):639-45.

13. Haeck IM, Knol MJ, Ten Berge O, van Velsen SG, de Bruin-Weller MS, Bruijnzeel-Koomen CA. Enteric-coated mycophenolate sodium versus cyclosporin $\mathrm{A}$ as long-term treatment in adult patients with severe atopic dermatitis: a randomized controlled trial. J Am Acad Dermatol 2011;64(6):1074-84.

14. Kwakkel-van Erp JM, Haeck IM, Paantjens AW, van de Graaf EA, van Ginkel WG, Knol MJ, et al. Differential usefulness of biomarkers thymus and activation-regulated chemokine and soluble CD30 during enteric coated mycophenolate sodium and cyclosporine therapy in atopic dermatitis. J Am Acad Dermatol 2010;63(3):e70-2.
15. Schmitt J, Schäkel K, Fölster-Holst R, Bauer A, Oertel R, Augustin M, et al. Prednisolone vs. ciclosporin for severe adult eczema: an investigator-initiated double-blind placebocontrolled multicentre trial. Br J Dermatol 2010;162(3):661-8.

16 Arellano FM, Wentworth CE, Arana A, Fernandez C, Paul CF. Risk of lymphoma following exposure to calcineurin inhibitors and topical steroids in patients with atopic dermatitis. J Invest Dermatol 2007;127:808-16.

17. Hagstromer L, Ye W, Nyren O, Emstestam L. Incidence of cancer among patients with atopic dermatitis. Arch Dermatol 2005;141:1123-7.

18. Dinić M, Kandolf Sekulović L, Mladenović T, Zečević R. Erythrodermic cutaneous T-cell lymphomas: two case reports. Serb J Dermatol Venereol 2009;1(3):116-21,

19. Bos JD, Leent EJ, Sillevis-Smitt JH. The millennium criteria for the diagnosis of atopic dermatitis. Exp Dermatol 1998;7:132-8.

\section{Abbreviations}

AD - atopic dermatitis

UV - ultra violet

IgE - immunoglobuline $\mathrm{E}$

PUVA - psoralen plus ultraviolet A

TNF- $\alpha$ - tumor necrosis factor-alpha

\section{Lečenje teškog oblika atopijskog dermatitisa sa ciklosporinom: prikaz serije od osam pacijenata}

\section{Sažetak}

Uvod. Atopijski dermatitis je hronično inflamatorno oboljenje kože koje se kod većine pacijenata leči lokalnom primenom emolijenasa, koritkosteroida i kalcineurinskih inhibitora. Međutim, kod 10-20\% bolesnika neophodna je sistemska terapija, a najčešće korišćeni modalitet sistemske terapije u svakodnevnoj praksi su sistemski kortikosteroidi, iako nema dovoljno proverenih podataka koji podržavaju njegovu upotrebu. S druge strane, efikasnost i neželjeni efekti ciklosporina dobro su definisani u randomizovanim kontrolisanim studijama i prema savremenim vodičima on je preporučen kao modalitet prvog izbora za teške oblike atopijskog dermatitisa, koji nemaju dobar terapijski odgovor na lokalnu terapiju i fototerapiju. Međutim, svega oko $10 \%$ pacijenata sa atopijskim dermatitisom, koji imaju indikaciju za lečenje ciklosporinom, zaista se i leči ciklosporinom. Nema objavljenih serija slučajeva o njegovoj upotrebi $\mathrm{u}$ ovom regionu. $\mathrm{U}$ ovom članku, mi smo analizirali efikasnost i bezbednost lečenja ciklosporinom kod pacijenata sa teškim oblikom atopijskog dermatitisa, lečenih na Vojnomedicinskoj akademiji u Beogradu od 2009. do 2012. godine.

Ispitanici i metode. Učinjena je restrospektivna analiza bolesnika sa teškim oblikom atopijskog dermatitisa lečenih na Klinici za kožne i polne bolesti VMA u periodu 2009-2012. godine a podaci su dobijeni iz bolničke baze podataka i medicinske dokumentacije. U navedenom periodu, približno 200 pacijenata lečeno je od atopijskog dermatitisa, 20 pacijenata je primljeno na bolničko lečenje, a 17 sa teškim oblikom bolesti. Ukupno 8 od 17 (47,05\%) hospitalizovanih pacijenata sa težim oblikom bolesti ili eritrodermijom izazvanom atopijskim dermatitisom lečeni su ciklosporinom sa prosečnom dozom od $4,5 \mathrm{mg} / \mathrm{kg}$ TT. Laboratorijske analize su uzete pre tretmana, posle 7 dana i/ili na kraju hospitalizacije. Terapijska efikasnost je ocenjena na osnovu procenta redukcije kožnih lezija 
od početka terapije do poslednjeg dana hospitalizacije (rana efikasnost) i do poslednjeg dana praćenja (kasna efikasnost). Trajanje terapije, neželjeni efekti tokom terapije, efikasnost lečenja i razlog za prekid lečenja beleženi su na kontrolnim pregledima pacijenata.

Rezultati. Ukupno je lečeno osam pacijenata, pet muškaraca i tri žene, prosečne starosti 36,8 godina (15-60 godina). Prethodni modaliteti lečenja kod svih bolesnika bili su topikalni i sistemski kortikosteroidi, PUVA terapija i emolijensi. Prosečna doza ciklosporina je bila 4,5 $\pm 0,5 \mathrm{mg} / \mathrm{kg}$. Srednja vrednost redukcije promena na koži poslednjeg dana hospitalizacije iznosila je $60 \%$, posle prosečno vremena hospitalizacije od $10 \pm$ 3,2 dana. Medijana trajanja terapije bila je 16 meseci (3-24), sa srednjom vrednošću redukcije promena na koži tokom praćenja od $75 \%$. Arterijski krvni pritisak je bio povećan kod 3 od 8 (37,5\%) bolesnika, bez obzira na starost, sa prosečnim porastom sistolnog krvnog pritiska od 11,9 \pm 11,6 mm Hg (prosečno 7,5, 0/30 $\mathrm{mm} \mathrm{Hg}$ ) i dijastolnog krvnog pritisaka 12,9 $\pm 5,6 \mathrm{~mm}$ $\mathrm{Hg}$ (prosečno 0, -10-20). Srednje povećanje vrednosti uree u serumu iznosilo je $0,3 \mathrm{mmol} / \mathrm{l}(11,8 \%)$, dok su vrednosti kreatinina bile povećane kod tri bolesnika (prosečno $4 \mathrm{mmol} / \mathrm{l}$ ). Tokom praćenja, hipertenzija je zabeležena kod tri bolesnika, dok ostali neželjeni efekti nisu evidentirani.

Zaključak. Na osnovu prethodnih studija i ove serije malog broja slučaja kod hospitalizovanih bolesnika sa teškim oblikom atopijskog dermatitisa, uključujući eritrodermiju, ciklosporin se može smatrati bezbednom i efikasnom terapijom i može se preporučiti kao prva linija terapije kod obolelih od teških oblika atopijskog dermatitisa koji ne reaguju na lokalnu terapiju i fototerapiju. Dugotrajnu terapiju, međutim, treba izbegavati, a preporučuje se maksimalno jedna do dve godine terapije.

\section{Ključne reči}

Atopijski dermatitis; Ciklosporin; Ishod lečenja; Imunosupresivni lekovi 